\title{
STANDING TO CHALLENGE GOVERNIMENTAL, ACTIONS WHICH HAVE AN INSUBSTANTIAL OR ATTENUATED EFFECT ON THE ENVIRONMENT
}

In United States v. Students Challenging Regulatory Agency Procedures (SCRAP), ${ }^{1}$ the Supreme Court held that plaintiffs who alleged that a certain administrative action had had a deleterious effect upon their use and enjoyment of the natural environment had standing to challenge that action in court, notwithstanding the fact that the causal connection between the administrative action and the harm alleged by the plaintiffs was concededly both tenuous and indirect. SCRAP, an association formed by five law students, ${ }^{2}$ challenged an Interstate Commerce Commission (ICC) order, which maintained the effectiveness of a 2.5 percent surcharge on national railroad freight rates, ${ }^{3}$ by contending that the order was invalid since the ICC had failed to file an environmental inpact statement nnder the National Environmental Policy Act (NEPA). ${ }^{4}$ The basis for SCRAP's claim

1. 412 U.S. 669 (1973).

HEREAFTER THE FOLIOWING CITATION WILL BE USED IN THIS NOTE:

Scott, Standing in the Supreme Court-A Functional Analysis, 86 HARv. L. REv. 645 (1973) [hereinafter cited as Scott].

2. The unincorporated association was formed at the George Washington University National Law Center in order "to enhance the quality of the human environment for its members, and for all citizens ..." 412 U.S. at 678, citing amended complaint in SCRAP v. United States, 346 F. Supp. 189 (D.D.C. 1972); see Aberdeen \& Rockfish R.R. v. SCRAP, 409 U.S. 1207, 1208 n.1 (1972). See also SCRAP v. United States, 346 F. Supp. at 191. Also intervening, pursuant to FED. R. Crv. P. 24, were the Environmental Defense Fund, Inc., the National Parks and Conservation Association, and the Izaak Walton League of America. 412 U.S. at 680 n.9.

3. Substantially all the railroads in the United States had filed with the Interstate Commerce Commission for a 2.5 percent surcharge on freight rates, to beconie effective in February, 1972. 412 U.S. at 675. The Interstate Commerce Act, $\$ 15$, 49 U.S.C. $\$ 15(7)$ (1970), provides that the Commission shall have the authority to suspend such a rate change for a seven unonth period pending an investigation and decision on the lawfulness of the new rates. Shippers, conpeting carriers, and others requested the Comnnission to utilize its authority under this provision to suspend the rates. On February 1, 1972, shortly before the surcharge was to automatically become effective unless suspended, the Comnission issued an unpublished order announcing its decision not to suspend the rate increase. 412 U.S. at 676. An unpublished order of April 24, 1972, permitted an extension of a 2.5 percent temporary surcharge. Id. at 677 .

4. Section 102 of NEPA requires, in part, that all agencies of the federal government shall 
was a contention that the increased freight rates had adversely affected the environment by discouraging the transportation of recyclable materials. This effect, the plaintiffs claimed, had in turn resulted in increased depletion of the area's natural resources through promotion of the use of new raw materials which compete with scrap and had added to the accumulation in the environment of otherwise recyclable materials in the form of refuse and waste. ${ }^{5}$ To establish standing SCRAP alleged that its members suffered "recreational and aesthetic harm" as a result of the Commission's action in that each of thein used the natural enviroument, both in and around the Washington, D.C., metropolitan area and in the areas of their legal residence, for recreational and aesthetic purposes. ${ }^{6}$ In response to this claim, the government contended that SCRAP was without standing to sue because it had "no more than a general interest in seeing that the law is enforced ...." After rejecting this defense and finding that the plaintiffs had standing to seek review, a three-judge district court granted a preliminary injunction against the order permitting the rate increase. ${ }^{8}$ On direct appeal, ${ }^{9}$ the Supreme Court held that the plaintiffs' allegations were sufficient to give thein standing to challenge the

(C) include in every recommendation or report on proposals for legislation and other Federal actions significantly affecting the quality of the huinan environment, a detailed stateinent by the responsible official on-

(i) the environmental impact of the proposed action,

(ii) any adverse environmental effects which cannot be avoided should the proposal be implemented,

(iii) alternatives to the proposed action,

(iv) the relationship between local short-term uses of man's environment and the maintenance and enhanceinent of long-term productivity, and

(v) any irreversible and irretrievable commitments of resources which would be involved in the proposed action should it be implemented. 42 U.S.C. \& 4332(2)(C) (1970).

5. 412 U.S. at 676 .

6. Id. at 678. SCRAP also asserted that its members had been injured by increased air pollution as a result of the inodified rate structure. Furthermore, SCRAP alleged that its members had been harmed economically, asserting that lack of recycling had increased the price of finished products which its members purchased and had increased the taxes which they paid. Id.

7. Id. at 681, quoting SCRAP v. United States, 346 F. Supp. 189, 195 (D.D.C. 1972), rev'd on other grounds, 412 U.S. 669 (1973).

8. 346 F. Supp. at 202. Initially, a single district court judge denied the defendant's motion to dismiss for lack of standing. Thereafter, a three-judge district court was colrvened pursuant to 28 U.S.C. $\S \S 2284,2325$ (1970). 346 F. Supp. at 194 n.7.

The three-judge court held that SCRAP lad met the standing requirements set forth by the Supreme Court in Association of Data Processing Serv. Organizations, Inc. v. Camp, 397 U.S. 150 (1970), and Barlow v. Collins, 397 U.S. 159 (1970). 346 F. Supp. at 195. The Data Processing and Barlow cases are discussed in notes 20-24 infra and accompanying text. The court also relied on NAACP v. Button, 371 U.S. 415 (1963), for the proposition that an organization whose members are injured may obtain judicial review ou behalf of such inembers. 
ICC action; ${ }^{10}$ however, it reversed on the merits, concluding that the district court lacked jurisdiction to enjoin the ICC rate order. ${ }^{11}$

Standing is a legal concept which eludes precise definition. ${ }^{12}$ The Supreme Court has observed that the concept is designed to ascertain whether a party has a sufficient stake in the resolution of a particular controversy to ensure that "the dispute sought to be adjudicated will be presented in an adversary context and in a form historically viewed as capable of judicial resolution."13 Thus, standing serves to

9. 28 U.S.C. $\$ 1253$ (1970) provides for direct appeals from three-judge federal district courts to the Supreme Court from any order granting or denying an injunction in a civil suit.

Following issuance of the injunction by the three-judge court and prior to the appeal to the Supreme Court, the Interstate Commerce Commission and the intervening railroads applied to the Chief Justice sitting as Circuit Justice for the District of Columbia for a stay of the district court's preliminary injunction. Aberdeen \& Rockfish R.R. v. SCRAP, 409 U.S. 1207 (Burger, Circuit Justice, 1972). However, the Chief Justice, finding that the district court had not abused its discretion in granting the injunctive relief, refused to issue the stay. Id. at 1217-18.

10. 412 U.S. at 690.

11. The Court concluded that the case before it was controlled by its earlier decision in Arrow Transp. Co. v. Southern Ry., 372 U.S. 658 (1963). In Arrow, the Court held that section 15 of the Interstate Commerce Act, 49 U.S.C. $\&$ 15(7) (1970), placed the power to suspend railroad rates exclusively in the hands of the Commission, thereby extinguishing the power of the courts to grant such relief. 412 U.S. at 691.

12. See Flast v. Cohen, 392 U.S. 83, 98-99 (1968). Quoting a statement by Professor Paul A. Freund before a Senate subconmittee, the Flast Court described the law of standing as "one of the most amorphous concepts in the entire domain of the public law." Id. at 99, citing Hearings on S. 1097 Before the Subcomm. on Constitutional Rights of the Senate Judiciary Comm., 89th Cong., 2d Sess. 498 (1966). See also Scanwell Labs., Inc. v. Schaffer, 424 F.2d 859, 861 (D.C. Cir. 1970). Standing has also been characterized as a "complicated specialty of federal jurisdiction." United States ex rel. Chapman v. FPC, 345 U.S. 153, 156 (1953). Professor Davis has endorsed this description and has further stated his view that this "complicated specialty . . . keeps on producing a large volume of wasteful litigation that in turn keeps on adding to the complexity." K. Davis $\$ 22.00-4$, at 722 (Supp. 1970) (footnote omitted). See also Albert, Standing to Challenge Administrative Action: An Inadequate Surrogate for Claims for Relief, 83 YALE L.J. 425, 497 (1974) (concept of standing is "opaque"). Professor Scott has observed that "these dccisions [the standing cases decided in the Supreme Court since 1968] have failed to establish a coherent and unified doctrine of standing that explains their results." Scott 660 .

The requirements of the law of standing are particularly pertinent to challenges of administrative actions generally. See C. Wright, LAw of Federal Courts 39 (2d ed. 1970). "The law of standing is almost exclusively concerned with such public law questions as determinations of constitufionality and review of administrative or otler governmental action." Id. (emphasis added).

13. Flast v. Cohen, 392 U.S. 83, 101 (1968). See also Sierra Club v. Morton, 405 U.S. 727 (1972), where the Court observed that the question of standing was an inquiry by a court into "[w] hether a party has a sufficient stake in an otherwise justiciable controversy to obtain judicial resolution of that controversy ...."Id. at 73132. 
assure the "concrete adverseness" necessary not only to allow proper judicial consideration of disputed issues ${ }^{14}$ but also to comply with the case and controversy requirements of article III. ${ }^{15}$ Unlike other doctrines developed to assist the courts in adjudicating disputes, the standing inquiry is concerned with the threshold determination of the relationship between the particular plaintiff and the issues he desires to litigate, rather than the merits of the question ${ }^{16}$ or the appropriateness of the issue itself for judicial determination. ${ }^{17}$

Section 10 of the Administrative Procedure Act ${ }^{18}$ (APA) provides judicial review to any party "adversely affected or aggrieved by agency action within the meaning of a relevant statute ...."10 Construing this language in the companion cases of Association of

14. See, e.g., Baker v. Carr, 369 U.S. 186, 204 (1962), where the Court observed that standing functioned "to assure that concrete adverseness which sharpens the presentation of issues upon which the court so largely depends for illumination of difficult - . questions."

15. U.S. CoNsT. art. III, $\S 2$. The Supreme Court has explicitly stated that the exercise of judicial power is limited to cases and controversies. See Muskrat v. United States, 219 U.S. 346 (1911), where the Court observed: "[T] power is limited to 'cases' and 'controversies.' Beyond this it does not extend, and unless it is asserted in a case or controversy within the meaning of the Constitution, the power to exercise it is nowhere conferred." Id. at 356. The question of standing is related to the article III limitations on the exercise of judicial power. See Flast v. Cohen, 392 U.S. 83,101 (1968) (taxpayer has standing to challenge legality of federal spending program). In Data Processing, the Court stated that "the question of standing in the federal courts is to be considered in the framework of Article III which restricts judicial power to "cases and controversies." 397 U.S. at 151. See also O'Shea v. Littleton, 42 U.S.L.W. 4139, 4141 n.2 (U.S. Jan. 15, 1974); Natural Resources Defense Council, Inc. v. EPA, 481 F.2d 116, 121 (10th Cir. 1973). But see Scott 673, where the author states "it is highly questionable that [the] standing doctrine has anything in turn to contribute to the implementation of the case or controversy requirement." For a contention that there is no historical basis for the concept of case and controversy as interpreted by the federal courts and that the Constitution does not demand an injury to a personal interest as a prerequisite to the attamment of standing, see Berger, Standing to Sue in Public Actions: Is It a Constitutional Requirement?, 78 YALE L.J. 816, 840 (1969).

16. See Association of Data Processing Serv. Organizations, Inc. v. Camp, 397 U.S. 150, 153 (1970); Barlow v. Collins, 397 U.S. 159, 171 (1970) (Brennan, J., concurring in part and dissenting in part). See note 23 infra.

17. For example, the issues of mootness, collusiveness, political question, ripeness, and reviewabihty are clearly distinguishable from the issue of standing in that standing, unlike these other concepts, focuses on the sufficiency of the claimant's interest in the case. See Scott 684. See also Barlow v. Collins, 397 U.S. 159, 171 (1970) (Brennan, J., concurring in part and dissenting in part), where Mr. Justice Brennan, citing Flast v. Cohen, 392 U.S. 83, 99-100 (1968), stated that the question of standing is neither a part of the above doctrines nor concerned with the merits of the case. 397 U.S. at 171 n.3. For a discussion of Barlow, see note 23 infra.

18. 5 U.S.C. $\$ \$ 701$ et seq. (1970).

19. Id. § 702 . 
Data Processing Service Organizations, Inc. v. Camp ${ }^{20}$ and Barlow v. Collins, ${ }^{21}$ the Supreme Court held that persons have standing to obtain judicial review of administrative action when they allege (1) injury in fact, as a result of the challenged action, and (2) injury to an interest which is arguably within the zone of interests protected by the statutory provisions allegedly violated..$^{22}$ Although the injuries asserted in both these cases were economic in nature, ${ }^{23}$ the Court in-

20. 397 U.S. 150 (1970).

21. Id. at 159.

22. Id. at 153. The Court rejected the contention that in order to acquire standing a plaintiff must allege and demonstrate the violation of soine "legal interest." Justice Douglas, speaking for the inajority, observed: "The 'legal interest' test goes to the merits. The question of standing is different." Id. The "legal interest" test had been most clearly articulated in Tennessee Elec. Power Co. v. TVA, 306 U.S. 118 (1939), where the Court observed that a plaintiff would have standing only where his right that had allegedly been invaded was "a legal right,-one of property, one arising out of contract, one protected against tortious invasion, or one founded on a statute ...."Id. at 137. Under this test, it is clear that an inquiry into a plaintiff's standing necessarily embraces a determination of the merits of his cause of action. See also Alabama Power Co. v. Ickes, 302 U.S. 464 (1938); The Chicago Junction Case, 264 U.S. 258 (1924); Edward Hines Yellow Pine Trustees v. United States, 263 U.S. 143 (1923); In re Ayers, 123 U.S. 443, 447 (1887).

Justice Brennan concurred in the granting of standing in Data Processing and Barlow, bnt dissented from the Court's announceinent of its bifurcated test of standing. 397 U.S. at 167. In criticizing the inajority's test, Justice Brennan observed:

My view is that the inquiry in the Court's first step [allegation of injury in fact] is the only one that need be made to determine standing. I had thought we discarded the notion of any additional requirement when we discussed standing solely in terms of its constitutional content in Flast v. Cohen, 392 U.S. 83 (1968). By requiring a second, nonconstitutional step, the Court comes very close to perpetuating the discredited requirement that conditioned standing on a showing by the plaintiff that the challenged governmental action invaded one of his legally protected interests. Id. at 168 .

23. In Data Processing, the plaintiff, who sold data processing services to bnsinesses, challenged a ruling of the Comptroller of the Currency allowing national banks to make these same services available to its banking cnstomers. 397 U.S. at 151 . The Court held that allegations by the plaintiff that the ruling had caused it to lose profits and former customers to banks were sufficient to constitute injury in fact. Id. at 152. Furthermore, the Court held that the competitive harm which the plaintiff was suffering was arguably within the zone of interests of section 4 of the Bank Service Corporation Act, 12 U.S.C. $\$ 1864$ (1970), which provides: "No bank service corporation may engage in any activity other than the performance of bank services for banks." The Court concluded that since both parts of the standing test had been met, the plaintiff had standing to challenge the ruling. 397 U.S. at 158.

In Barlow, a group of tenant farmers challenged a regulation proinulgated by the Secretary of Agriculture which relaxed restrictions on the contractual assignments of crop support payments inade pursuant to section 402 of the Food and Agriculture Act of 1965, 7 U.S.C. $\$ 1444$ (d) (1970). The farmers alleged that the regulation would facilitate the landlords' practice of requiring tenants to assign support payments as a precondition to obtaining a lease to work the land. This, the tenant farmers urged, wonld leave them without the necessary cash to purchase their supplies and make them dependent on the landlords for credit at exorbitant rates and, therefore, would make it 
dicated in dicta in Data Processing that noneconomic injuries could also satisfy the injury in fact requirement. ${ }^{24}$

In Sierra Club v. Morton, ${ }^{25}$ the Court applied the standing test articulated in Data Processing to a plaintiff seeking to challenge administrative action which, the plaintiff alleged, would adversely affect the environment. The plaintiff, an environmental organization, ${ }^{26}$ sought to enjoin the granting of permits by the Secretary of the Interior which allowed, inter alia, construction of a road and power line into Mineral King Valley and Sequoia National Park in connection with the development of a recreational resort. ${ }^{27}$ The plaintiff brought suit as an organization with a "special interest in the conservation and the sound maintenance of the national parks, game refuges and forests of the country,"28 asserting that it was a party "adversely affected or aggrieved by agency action" within the meaning of section 10(a) of the APA. ${ }^{29}$ In order to ascertain whether the first branch of the bifurcated Data Processing test had been satisfied, the Court examined the plaintiff's allegations that the proposed development "would destroy or otherwise adversely affect the scenery, natural and historic objects and wildlife of the park . . . for future generations."3o Significantly, the Court explicitly confirmed what it had indicated in Data Processingthat aesthetic and environmental injuries are sufficient to constitute injury in fact. ${ }^{31}$ Moreover, it noted that "the fact that particu-

impossible for them to earn a profit. The Court held that the plaintiffs' allegations of economic hardship constituted injury in fact and thereby assured the personal stake required by the article III, section 2 case and controversy requirements. The Court also found that the tenant farmers' interests were within the zone of interests of section 402 of the Food and Agriculture Act of 1965 which provides: "The Secretary shall provide adequate safeguards to protect the interests of tenants . . ." 7 U.S.C. \& 1444(d)(10) (1970). 397 U.S. at 164, 167.

24. The Data Processing Court discussed various noneconomic values including aesthetic, conservational, and recreational values, and even a spiritual stake in first amendment values and concluded: "We mention these noneconomic values to emphasize that standing may stem from them as well as from the economic injury on which petitioners rely here." 397 U.S. at 154.

25. 405 U.S. 727 (1972).

26. Id. at 735 n.8. The Sierra Club alleged in its complaint that it was a nonprofit corporation, organized and operating under the laws of California, with its principal place of busimess in San Francisco. Furthermore, the Club alleged that its principal purpose was to protect and preserve the natural resources of the Sierra Nevada Mountains and that it served as the responsible representative of those interested in these resources. The Sierra Club had 27,000 members in the Bay Area and 78,000 members nationally. Id.

27. Id. at $730 \mathrm{n} .2$.

28. Id. at 735 n.8.

29. 5 U.S.C. $\& 702$ (1970). See text accompanying notes 18-19 supra.

30. 405 U.S. at 734.

31. Id. At least one commentator has suggested that the primary importance 
lar environmental interests are shared by the inany rather than the few does not make them less deserving of legal protection . . . ..332 However, the Court reasoned that a cognizable injury by itself is insufficient to comply with the requirement of injury in fact. Rather, that test requires that the particular party seeking review be among the injured. ${ }^{33}$ Consequently, the Court concluded that the plaintiff had not met the injury in fact requirement since it had not alleged that either the Club itself or its members actually used the area which was threatened by the projected development. ${ }^{34}$ After noting that the Club had failed to state "that its members use Mineral King for any purpose, much less that they use it in any way that would be significantly affected by the proposed actions of the respondents,"35 the Court rejected the Club's argument that it could establish the requisite injury in fact by alleging harm to the public interest, which it claimed to represent. In so doing, the Court observed that the public interest could be asserted only after the litigant itself had established standing in its own right. ${ }^{3 e}$ Having found that the injury in fact portion

of Sierra Club lies in its "affirmation, if not holding, that harm of a noneconomic nature to an individual may constitute injury in fact for standing purposes." Scott 667. The Court observed that it did "not question that this type of harm [aesthetic and environmental] may amount to an 'mjury in fact' sufficient to lay the basis for standing under $\$ 10$ of the APA [5 U.S.C. $\$ 702$ (1970)]." 405 U.S. at 734.

In addition to the dicta in Data Processing, see note 24 supra and accompanying text, other courts have suggested that aesthetic or noneconomic injury could constitute mjury in fact. See Scemic Hudson Preservation Conference v. FPC, 354 F.2d 608 (2d Cir. 1965), cert. denied, 384 U.S. 941 (1966), where the grant of a license to set up a hydroelectric plant at Storm King Mountain was challenged under section 313(b) of the Federal Power Act, 16 U.S.C. $\$ \S 791(a), 825(b)$ (1970). The court suggested that those who exhibited a special interest in the recreational, aesthetic, or conservational aspects of power development would be aggrieved under the statute. 354 F.2d at 616. However, the court limited the value of this statement as persuasive precedent by subsequently observing that some of the plaintiffs had suffered economic injury even though, im the court's opinion, it was not required to establish standing. See also Environmental Defense Fund, Inc. v. Hardin, 428 F.2d 1093 (D.C. Cir. 1970); Office of Communication of the United Church of Christ v. FCC, 359 F.2d 994, 1005 (D.C. Cir. 1966); Reade v. Ewing, 205 F.2d 630, 631-32 (2d Cir. 1953); Crowther v. Seaborg, 312 F. Supp. 1205, 1212 (D. Colo. 1970).

32. 405 U.S. at 734 .

33. Id. at 735. The Court further stated that an organization whose members are injured may seek judicial review as a representative of such members. Id. at 739, citing NAACP v. Button, 371 U.S. 415,428 (1963).

34. 405 U.S. at 735.

35. Id. (emphasis added).

36. Id. at 737. In Scripps-Howard Radio, Inc. v. FCC, 316 U.S. 4 (1942), plaintiff Scripps-Howard challenged a grant by the FCC of a broadcast license to another radio station, alleging that the agency could not lawfully grant the license without a hearing, that in doing so the FCC had departed from its own rules, that the grant did not serve the public interest since it had the effect of depriving local histeners of 
of the test had not been satisfied, the Court did not consider whether the plaintiff met the zone of interests branch of the Data Processing dual standing requirement. ${ }^{37}$

Despite the result reached in Sierra $\mathrm{Clu}^{38}{ }^{88}$ the Court made clear

non-network service, and that the Commission thus violated the due process clause of the fifth amendment. Id. at 5 . In challenging the grant the plaintiffs acted in accordance with the judicial review provision of the Communications Act of 1934, $\$ 402$ (b) (2), ch. 652, 48 Stat. 1093, as amended, 47 U.S.C. \& 402(b)(6) (1970). See 316 U.S. at 14. The Court observed that the purpose of the Act was to protect the public interest in communications and continued: "[T] hese private litigants have standing only as representatives of the public interest" Id. See also FCC v. Sanders Bros. Radio Station, 309 U.S. 470, 475-76 (1940) (suggesting that the congressional purpose of the Federal Communications Act of 1934 was to protect the public interest and that economic harm need not be shown by a plaintiff to challenge the grant of a license to another station).

In Sierra Club, the Court rejected the plaintiff's attempt to rely on Scripps-Howard and Sanders as support for the proposition that one could obtain standing to challenge administrative action solely as a responsible representative of the public interest:

Taken together, Sanders and Scripps-Howard thus established a dual proposition: the fact of economic injury is what gives a person standing to seek judicial review under the statute, but once review is properly invoked, that person may argue the public interest in support of his claim that the agency has failed to comply with its statutory mandate. 405 U.S. at 737.

But see Citizens Comm. for the Hudson Valley v. Volpe, 425 F.2d 97, 105 (2d Cir.), cert. denied, 400 U.S. 949 (1970); Scenic Hudson Preservation Conference v. FPC, 354 F.2d 608, 616 (2d Cir. 1965), cert. denied, 384 U.S. 941 (1966).

The Court then noted: "The test of mjnry in fact goes only to the question of standing to obtain judicial review. Once this standing is established, the party may assert the interests of the general public in support of his claims for equitable relief." 405 U.S. at 740 n.15.

37. 405 U.S. at 733 n.5.

38. Justice Douglas dissented from the Court's holding in Sierra Club, observing:

The critical question of "standing" would be simplified and also put neatly in focus if we fashioned a federal rule that allowed environmental issues to be litigated before. . federal courts in the name of the manimate object abont to be despoiled, defaced, or invaded . . . and where injury is the subject of public outrage. Id. at 741 .

Justice Douglas analogized the bringing of an action in the name of the despoiled environmental resource to a salvage action in admiralty law brought in the name of the rescuing vessel. Id. at 742 n.2.

Mr. Justice Blackmun also dissented in Sierra Club, criticizing the inflexibility of standing concepts in the face of the special needs of environmental protection. Id. at 755. He proposed that an environmental organization with "pertinent, bona fide, and well-recognized attribntes and purposes" be allowed to litigate environinental issues. Id. at 757. Justice Blackmun expressed the fear that actual users of the park might have an economic motivation to favor its development and would thus be an unlikely adversary to challenge the alleged environmental injury. Id. at 759. His fear was that strict standing requirements in the environmental area would discourage serious opposition by groups protecting the environment. Id. at 756.

The Court's denial of standing has been criticized by various commentators. Professor Scott has objected to the line drawn in the decision between past and potential future users and those persons who might appreciate Mineral King Valley pictorially or symbolically. Scott 692. See also Note, Standing to Sue in Federal Courts to Pre- 
that aesthetic and other noneconomic injuries could constitute injury in fact. ${ }^{39}$ Moreover, if the litigant itself has been injured by the challenged agency action, it was deemed irrelevant by the Sierra Club Court that its imjuries were shared by a larger segment of the public. ${ }^{40}$

In contrast to the plaintiff in Sierra Club, the environmental organizations challenging the validity of the ICC orders in $S C R A P$ specifically alleged that the orders would adversely affect its members' use of the natural resources. ${ }^{41}$ As noted above, the plaintiffs' inain contention was that the Commission's orders were illegal because they had been issued without compliance with the impact statement requirements of NEPA. ${ }^{42}$ Examining the question of whether the plaintiffs had standing to obtain judicial review of the challenged order, the Supreme Court initially noted that the plaintiffs clearly met the zone of interests test simce the environmental interest asserted was undoubtedly within the interests to be protected by NEPA. ${ }^{48}$ Turning to the imjury in fact requirement, the Court distinguished Sierra Club on the grounds that in that case the organization had merely claimed to be a representative of the public interest because of its long-standing interest in environmental protection and had failed to allege that it or its members would be adversely affected in their activities by the agency action complained of. ${ }^{44}$ Referring to its dicta in Sierra Club, ${ }^{45}$ the Court reaffirmed the proposition that noneconomic injuries are sufficient to constitute injury in fact. ${ }^{46}$ Moreover, the Court rejected the argument that the plaintiffs lacked standing since the alleged effect of the national freight increase was no different upon the Washington area than upon the rest of the nation. ${ }^{47}$ The Court reasoned that "[ [] $\mathrm{O}$

vent Governmentally Sponsored Insults to the Environment: The Aftermath of Sierra Club v. Morton, 41 U. CINN. L. Rev. 669, 685 (1972); 11 DuQuesNe L. Rev. 165, 182 (1972); 38 Mo. L. REv. 292, 297 (1973).

39. Several lower federal court cases have apphed the holding in Sierra Club that injuries to noneconomic or aesthetic interests may constitute injury in fact. See, e.g., Environmental Defense Fund v. TVA, 468 F.2d 1164 (6th Cir. 1972), application for stay denied, 94 S. Ct. 535 (1973) (construction of dam would injure the recreational use of the Little Tennessee River); Sierra Club v. Leshe Salt Co., 354 F. Supp. 1099 (N.D. Cal. 1972) (improper construction of dikes threatened the use of the San Francisco Bay for fishing, sailing, and enjoyment of its scenic beauty); Sierra Club v. Mason, 351 F. Supp. 419 (D. Conn. 1972) (dredging project harmed use of the New Haven harbor for recreational purposes).

40. 405 U.S. at 734.

41. 412 U.S. at 687.

42. See note 4 supra and accompanying text.

43. 412 U.S. at $686 \mathrm{n} .13$. See note 59 infra and accompanying text.

44. Id. at 687. See note 35 supra and accompanying text.

45. See note 31 supra and accompanying text.

46. 412 U.S. at 686 .

47. In rejecting this argument, the Court stated: 
deny standing to persons who are in fact injured simply because inany others are also injured, would mean that the most injurious and widespread Government actions could be questioned by nobody."48 Furthermore, the Court refused to accept the government's argument, apparently based upon the Court's language in Sierra Club, that standing should be confined to those persons who have been significantly affected by agency action. Rather, the Court stated that the injury in fact requirement functioned "to distinguish a person with a direct stake in the outcome of a litigation-even though small-from a person with a mere interest in the problem." 49

Finally, the Court considered the government's contention that the plaintiffs' allegations that the general freight increase would adversely affect the environment were merely "a ploy to avoid the need to show some injury in fact." mental injury asserted in $S C R A P$ was "far less direct and perceptible" than that in Sierra Club and observed an "attenuated line of causation" between the agency action and ijury complained of. ${ }^{.1}$ Although the Court stated that "pleadings must be something more than an ingeni-

\footnotetext{
Unlike the specific and geographically limited federal action of which the petitioner complained in Sierra Club, the challenged agency action in this case is applicable to substantially all of the Nation's railroads, aud thus allegedly has an adverse environmental impact on all the natural resources of the country. Rather than a limited group of persons who used a picturesque valley in California, all persons who utilize the scenic resources of the country, and indeed all who breathe its air, could claim harn similar to that alleged by the environmcntal groups here. But we have already nuade it clear that standing is not to be denied simply because many people suffer the same injury. Id. at 687, citing Environmental Defense Fund, Inc. v. Hardin, 428 F.2d 1093, 1097 (D.C. Cir. 1970); Reade v. Ewing, 205 F.2d 630, 631-32 (2d Cir. 1953).
}

48. 412 U.S. at 688.

49. Id. at 689 n.14. See note 35 supra and acconpanying text. See also Davis, Standing: Taxpayers and Others, 35 U. Crn. L. REv. 601, 613 (1968), where the author states that "[f]ederal law is clear that standing may rest upon a trifle, and it is equally clear that at least a trifling imterest of the plaintiff is always required."

50. 412 U.S. at 688. The railroads, which had intervened as defendants, argued that SCRAP would never be able to denonstrate that a general rate increase would have the adverse environmental impact alleged. Id. (For a discussion of plaintiffs' allegations, see notes 5, 6 supra aud accompanying text.) The Court stated that it was not certain that such allegations were not capable of proof. Moreover, the Court observed that if the "allegations were in fact untrue, then the appellants should have moved for summary judgment on the standing issue and demonstrated to the District Court that the allegations were sham and raised no genuine issue of fact." Id. at 689.

51. 412 U.S. at 688 . The Court observed that the plaintiffs had asked it

to follow a far more attenuated line of causation to the eventual injury of which the appellees complained - a general rate increase would allegedly cause increased use of nonrecyclable commodities as compared to recyclable goods, thus resulting in the need to use inore natural resources to produce such goods, some of which resources might be taken from the Washington area, and resulting in more refuse that might be discarded in national parks in the Washington area [because of less recycling]. Id. 
ous exercise in the conceivable," tions so specious as to be incapable of proof at trial, and therefore concluded that the plaintiffs had standing to obtain review. ${ }^{53}$ However, on the merits, the Court found that the district court lacked jurisdiction to enjoin the ICC orders. ${ }^{54}$

Dissenting on the issue of standing, Justice White, joined by Chief Justice Burger and Justice Rehnquist, argued that the plaintiffs' injuries were too "reinote, speculative and insubstantial" to constitute mjury in fact. ${ }^{55}$ Rather, he considered the allegations in SCRAP coin-

52. Id. However, in applying the standing requirements of Data Processing and Sierra Club, some lower federal courts have indicated that they view the allegation of injury in fact as merely a technical pleading requirement. In Citizens for Clean Air, Inc. v. Corps of Eng'rs, 349 F. Supp. 696 (S.D.N.Y. 1972), a district court discussed the propriety of a motion to dismiss for lack of standing:

Rather than engage in this technical pirouette, we believe the sounder course

is to deny the motion to dismiss for lack of standing on the condition that

plaintiffs amend the complaint within 20 days to make the pleadings of stand-

ing explicit rather than implicit. Id. at 705.

In a much more direct fashion, the court in National Ass'n for Community Dev. v. Hodgson, 356 F. Supp. 1399 (D.D.C. 1973), characterized the holding in Sierra $C l u b$ as "really of a rather limited, technical nature - a matter of pleadings." Id. at 1405. In dealing with the standing question before it, the court expressly relied on the note in Sierra Club, 405 U.S. at 735 n.8, where the Court had expressly left open the possibility that the plaintiff might obtain standing by merely amending its complaint to properly allege injury in fact. See also Sierra Club v. Mason, 351 F. Supp. 419, 424 (D. Conn. 1972) (injury in fact would be found by court where it could be reasonably inferred from facts alleged).

One cominentator has concluded that as a result of Data Processing and Sierra $C l u b$, proper pleading by a prospective plaintiff has become a central issue in standing cases:

It would present no great difficulty for the Sierra Club to allege that it represents its members rather than the public, and to find among its inembers users of Mineral King who would regard it as despoiled by the development. And now forewarned, other "public interest" organizations will plead in the proper form .... Scott 667 .

53. 412 U.S. at 690 . Writing for the concurrence, in which he was joined by Justice Brennan, Justice Blackmun reaffirmed the views he expressed in his dissenting opinion in Sierra Club, see note 38 supra, that "responsible and sincere" environmental organizations should have standing to assert injuries to the environment. 412 U.S. at 699.

54. See note 11 supra.

Justice Douglas, who had concurred with the majority's holding on the standing question, dissented from the opinion on the merits. In his opinion, Justice Douglas set forth the impact which recycling has upon the environment, 412 U.S. at 700, and noted the extent to which the railroad freight rate structure affects the use of the recycling process, $i d$. at 704-05. He contended that the majority's reliance upon Arrow Transp. Co. v. Southern Ry., 372 U.S. 658 (1963) (see note 11 supra), was misplaced inasnuch as Arrow precluded judicial relief only where the ICC las not yet acted. 412 U.S. at 711. However, Justice Douglas argued that the order in SCRAP had the same effect as an order which sets rates, and therefore should be subject to judicial review. Id. at 712 .

55. 412 U.S. at 723. Justice White also observed that 
parable to "the general interest allegations found insufficient and too remote in Sierra Club." that the finding of standing in SCRAP contravened the case and controversy requirements of article III. ${ }^{.7}$ Justice White suggested that the inajority's opinion, in essence, conferred upon any citizen who disagrees with governmental action the right to challenge that action in court. ${ }^{68}$

After SCRAP it would seen apparent that the bifurcated test of standing announced in Data Processing poses no substantial obstacle to those seeking judicial review of administrative actions which allegedly have a pernicious impact upon the environment. First, as the Court in $S C R A P$ inplicitly recognized, environmental statutes such as NEPA are sufficiently broad as to include practically any asserted environmental interest within the zone of interests protected by such statutes. ${ }^{59}$ Consequently, a plaintiff bringing suit to challenge agency ac-

[t]he majority acknowledges that these allegations reflect an "attenuated line of causation," but is willing to suspend its judgment in the dim hope that proof at trial will in some unexplained way flesh them out and establish the necessary nexus between these appellees and the across-the-board rate increase they complain of. Id. at 722-23 (citation omitted).

56. Id. at 723 .

57. "The allegations here do not satisfy the threshold requirement of injury in fact for constituting a . . case or controversy." Id. at 722 .

58. Justice White alluded to this problem when he observed: "If [the allegations] are sufficient here, we are well on our way to permitting citizens at large to litigate any decisions of the Government which fall in an area of interest to them and with which they disagree." Id. at 723.

59. In view of the broad purposes of NEPA, it would appear difficult, if not impossible, for a plaintiff asserting an environmental cause of action to fail the zone of mterests branch of the test where a violation of the statute is alleged. This is demonstrated by the fact that section 2 of NEPA, 42 U.S.C. $\S 4321$ (1970), states that:

The purposes of this chapter are: To declare a national policy which will encourage productive and enjoyable harmony between man and his environment; to promote efforts which will prevent or eliminate damage to the environment and biosphere and stimulate the health and welfare of man .... See also section 101(a) of the Federal Water Pollution Control Act Amendments of 1972, 33 U.S.C.A. § 1251(a) (Supp. 1974), amending 33 U.S.C. $\S \S 1151$ et seq. (1970).

For examples of recent environmental cases where the interests of plaintiffs allegedly imjured by illegal activities were found to be within the zone of interests of NEPA, see Environmental Defense Fund v. TVA, 468 F.2d 1164, 1171 (6th Cir. 1972), application for stay denied, 94 S. Ct. 535 (1973) (plaintiffs' recreational and cconomic interests in river which were threatened by development held to be within NEPA); Harlem Valley Transp. Ass'n v. Stafford, 360 F. Supp. 1057, 1064 (S.D.N.Y. 1973) (pollution of air and water used by plaintiffs found to be within zone of interests of NEPA); Sierra Club v. Mason, 351 F. Supp. 419, 422 n.1 (D. Conn. 1972) (threat to recreational and aesthetic uses of harbor by dredging held within zone of interests of NEPA). See also Davis v. Ronmey, 355 F. Supp. 29, 36 (E.D. Pa. 1973), vacated on other grounds, 490 F.2d 1360 (3d Cir. 1974) (nonenvironmental case where district court lield that zone of interests test would be satisfied by 
tion which allegedly violates such a statute should encounter little difficulty in meeting the zone of interests test.

Similarly, the SCRAP Court's unwillingness to require that a plaintiff be significantly affected by agency action, together with its refusal to closely scrutinize a concededly attenuated causal connection between the asserted injury and the challenged action, suggest that a prospective environmental plaintiff will find little difficulty complying with the requirement of mjury in fact. Thus, it appears that the Court in effect has adopted a private attorney general concept in environinental cases. ${ }^{60}$ To be sure, an environmental plaintiff must allege that the contested administrative action affects him in some manner. ${ }^{61}$

"any interest a statute may contemplate," economic or otherwise).

At least three commentators have observed that the zone of interests test is particularly easy to satisfy, both generally and in environmental suits. Professor Scott suggests that "relatively weak" indicia of protective intent may suffice. Scott 665 . See also Sedler, Standing, Justiciability and All That: A Behavioral Analysis, 25 VAND. L. REv. 479, 489 (1972) (zone of interests test no longer has any independent significance); Hasl, Standing Revisited-The Aftermath of Data Processing, 18 ST. Lours L.J. 12,37 (1973) (zone of interests test easy to meet in environmental actions).

60. The private attorney general concept was introduced in Associated Indus. v. Ickes, 134 F.2d 694 (2d Cir.), vacated as moot, 320 U.S. 707 (1943). The court in Ickes suggested that Congress could constitutionally enact a statute conferring on any non-official person the authority to bring suit to prevent the violation of an official's statutory powers. The court reasoned that there would be a controversy even if the plaintiff's sole purpose was to vindicate the public interest. 134 F.2d at 704 (emphasis added). See also Citizens Comm. for Hudson Valley v. Volpe, 425 F.2d 97, 105 (2d Cir.), cert. denied, 400 U.S. 949 (1970); Office of Communication of the United Church of Christ v. FCC, 359 F.2d 994, 1001 (D.C. Cir. 1966). See generally Jaffe, The Citizen as a Litigant in Public Actions: The Non-Hohfeldian or Ideological Plaintiff, 116 U. PA. L. REv. 1033 (1968).

In his dissent in Sierra Club and concurrence in SCRAP, Justice Blackmun articulated a similar, although demonstrably narrower, position by advocating a relaxation of traditional standing requirements in environmental suits, allowing an organization with a sincere, dedicated, and established status in environmental inatters to assert injuries to the environment without any further showing that its own interests have been affected. 405 U.S. at 757-58, 412 U.S. at 699 . See notes 38,53 supra.

However, the standards by which a court would determine whether an organization has a provable, sincere, dedicated, and established status in the environment might be difficult to articulate, and even more difficult for a court to apply.

Other commentators have expressed support for a great relaxation of traditional standing requirements in environmental actions. See Note, supra note 38, at 676-77; 39 BrookryN L. Rev. 492, 503 (1972); 38 Mo. L. Rev. 292 (1973). However, Professor Davis has observed that "[e]ven though the law of standing is so cluttered and confused that almost every proposition has some exception, the federal courts have consistently adhered to one major proposition, without exception: One who has no interest of his own at stake lacks standing." 3 K. DAvis $\$ 22.09-6$, at 753 (Supp. 1970).

61. The degree of attenuation between the challenged action and harm alleged which the courts will allow in finding the injury in fact test satisfied must await further judicial pronouncements. It is clear, lowever, that there must be some allegation of injury in fact by a prospective plaintiff who attempts to invoke judicial review of gov- 
However, $S C R A P$ clearly suggests that the injury may be insubstantial or indirect and yet constitute injury in fact. ${ }^{62}$

The liberal view of standing reflected by the SCRAP opinion limits the usefulness of standing as a concept for restricting access to the judicial process to those plaintiffs with a personal stake in the matter to be litigated. ${ }^{63}$ Standing has traditionally functioned to assure the adverseness necessary to coinply with the case and controversy requirements of article III. ${ }^{64}$ A tiberal interpretation of the standing requirement serves to promote greater availability of judicial scrutiny of administrative action which may adversely affect the environment; ${ }^{05}$ however, allowing plaintiffs with remote or insubstantial injuries to obtain that review potentially converts the courts to forums for the vindication of individual value preferences rather than for the resolution of concrete legal disputes. ${ }^{66}$ Such a development would not only dras-

ernmental actions. In Natural Resources Defense Council, Inc. v. EPA, 481 F.2d 116 (10th Cir. 1973), the plaintiff environmental organization and several individuals petitioned the circuit court for review of the EPA's approval of clean air impleinentation plans of several states pursuant to a provision of the Clean Air Act Amendinents of 1970, which provides:

A petition for review of the Administrator's action in approving or promulgating any implementation plan under [the Act] ... may be filed only in the United States Court of Appeals for the appropriate circuit. 42 U.S.C. $\S 1857 \mathrm{~h}-5$ (b) (1) (1970).

The court observed that the organizational plaintiff had failed to allege its purposes, who its members were, and any harm suffered by thein as a result of the approval of the plans. 481 F.2d at 117-18. Furthermore, none of the individual plaintiffs had alleged they were citizens, residents, voters, or taxpayers of any of the three affected states, or that they would be affected or aggrieved by the approval. Id. at 118. Observing that even though the statutory review provisions contained no requirement that a petitioner be adversely affected or aggrieved, as does section 10(a) of the APA, 5 U.S.C. $\$ 702$ (1970), the court stated: "We beheve that Art. III is controlling and that petitioners lack standing because they fail to state any injury in fact and hence do not present a case or controversy within the constitutional mandate." 481 F.2d at 121.

62. See note 51 supra and accompanying text.

63. See notes 15-17 supra and accompanying text.

64. See note 15 supra aud accompanying text.

65. For an expression of judicial horror at the possibly disruptive effects that unlimited access to federal courts could have on agency and governinental activities, see Alameda Conservation Ass'n v. California, 437 F.2d 1087 (9th Cir.), cert. denied, 402 U.S. 908 (1971), where the court rejected the protection of the public interest as conferring standing: "Were it otherwise the various clubs, political, economic and social now or yet to be organized, could wreak havoc with the adinimistration of government, both federal and state." Id. at 1090.

66. In Sierra Club v. Morton, 405 U.S. 727 (1972), the Supreme Court noted that limiting standing to those plaintiffs who have been individually harmed by administrative action

serve[s] as at least a rough attempt to put the decision as to whether review

will be sought in the hands of those who have a direct stake in the outcome. 
tically alter the traditional concept of the judicial function but also arguably contravene the constitutional requirements that federal judicial determinations be made only in the context of a case or controversy.

That goal would be undermined were we to construe the APA to authorize judicial review at the behest of organizations or individuals who seek to do no more than vindicate their own value preferences through the judicial process. Id. at 740 .

Furthermore, the Court observed that "judicial review is effective largely because it is not available simply at the behest of a partisan faction but is exercised only to remedy a particular, concrete injury." Id. at 740 n.16. It inay be argued that the extremely liberal interpretation of the injury in fact concept revealed in SCRAP creates the substantial possibility that plaintiffs who have actually suffered no concrete injury nevertheless inay obtain judicial review. Thus, practical elimination of standing as an effective threshold device for determining whether a particular plaintiff is the proper party to seek judicial relief may lead to the very result which the Court condemned in Sierra Club. 